\title{
Perspectival Political Theory
}

\author{
Daniel O'Neill and Michael Bernhard
}

\section{Political Theory's Place in Perspectives on Politics}

\}

ore than a quarter century ago political science's leading disciplinary historian, John Gunnell, offered a searing indictment of political theory as practiced in the early 1990s. Those were the days of an ostensible détente following the wars over behavioralism. However, in The Descent of Political Theory, Gunnell argued that despite all of its drawbacks as a mode of understanding politics, behavioralism had played an important role in uniting his subfield against a common enemy, thus giving it a shared sense of purpose. Deprived of the "tentative solidarity of antibehavioralism" after the 1960s, Gunnell lamented, political theory had become increasingly "fractured into a number of parochial professionally and intellectually inspired discursive enclaves" (Gunnell 1993, 268).

On the one hand, he concluded, this meant that political theory had "little to say to or about political science, while much of the literature of political theory is of marginal interest and intelligibility to political scientists" (Gunnell 1993, 2). On the other hand, political theory's deepening pluralism with respect to what it understood as appropriate objects of inquiry, as well as the expansion in the number of methodological approaches to studying those objects, represented a particularly poignant example of the history of academics' relationship to American public life. The proliferation of subject matter and approach, along with the subfield's inward turn to internecine squabbles about these issues, meant that "political theory ceased to speak about actual politics, let alone to it" (Gunnell 1993, 277).

Gunnell's book was written prior to the Perestroika movement, and to the creation of Perspectives on Politics. However, neither his assessment of the relationship between political theory and the rest of political science, nor that of political theory and "actual" politics would seem to have changed substantially since then. With respect to the latter, in his essay "Pluralism and the Fate of Perestroika," written for a "Reflections Symposium" in this journal in 2015, Gunnell noted that while he shared concerns about the political science profession's "alienation from politics," he was "less sanguine" about claims "that political theory has remained a redemptive beacon" shining the way to a better future. Instead, he reiterated his reading of the late Sheldon Wolin's principal worries - "that the 'proliferation' of theory reflected the disintegration of the political itself and that the vocation was in danger of losing touch with the "real" political world,' and that it might 'lapse into dilettantism' or 'harden into professionalism,' and become an array of 'postpolitical perspectives"' (Gunnell 2015b, 429).

Of course, Gunnell was quick to point out that he did not oppose methodological pluralism in political science (or political theory) any more than he did political pluralism within democratic societies, and he described Perestroika as a reform movement that had produced "professional and disciplinary changes" that "were salutary and responsive to growing concerns within the field" (Gunnell 2015b, 429). Behavioralists had mistakenly sought to make political scientists the purveyors of a brand of authoritative and objective scientific knowledge, believing that in so doing they would open the doors to practical political relevance, a move which in fact not only failed on its own epistemological terms, but had the paradoxical effect of distancing the profession-through increasing specialization-from the world of politics it sought to influence. Against that backdrop, deepening methodological pluralism was indeed salutary. However, Gunnell argued that such pluralism was not, itself, synonymous with making political science matter for a democratic society and that, pushed to its logical extreme, it might even undermine the discipline's ability to speak with a distinct (if not unified) critical voice on issues of pressing political concern. As Gunnell put it: "For criticism to be effective it must be taken seriously, and a discipline that seeks its identity in diversity is especially weakly positioned" (Gunnell 2015a, 414).

There are many possible responses to this description of the current state of the discipline in general, and the subfield of political theory in particular, a number of which were offered in the 2015 "Reflections Symposium." From our standpoint as the current editors of Perspectives on Politics, we would add that as a subfield today, political theory's substantive and methodological pluralism is not an outlier. We have published dozens of 
articles and invited, commissioned, and edited hundreds of reviews (across all fields of political science) as the APSA's official book review outlet for two-and-a-half years now. In doing so, we have been struck by the broad range in all of the subfields' conceptions of their subject matter and how best to approach it (one might look at recent books published in International Relations as but one striking example of this phenomenon). A similar bird's-eye view leads us to conclude that there is a good deal more cross-pollination of subject matter and approach between all subfields of political science and political theory than there was twenty-five years ago. Perestroika is at least in part responsible for that beneficial shift, even while neopositivism remains deeply influential, if not dominant, in the discipline.

More broadly, we would contend that the fate of the relevance of political theory for the "real" political world today is not as dire as Gunnell paints it. While it is true that political theory as a subfield evinces deep divisions, at a sufficiently high level of abstraction we would agree with Anne Norton's unifying claim that "for theorists, the questions that matter are questions concerning power: questions that are, or once were, or ought to be at the heart of political science." As Norton notes, a normative concern with power necessarily encompasses a very wide range of issues including "resistance, legitimacy, efficacy, dominion and oppression" (Norton 2015, 425). To these can be added a myriad of other concerns related to power, such as questions of justice and injustice, freedom and equality, as well as issues surrounding power's institutional embodiment, its relationship to race and gender, the conceptual clarification of its meaning, its history, its connection to class and ideology, and many others. If this is so, then the operative question becomes whether political theory's distinctive brand of pluralism can be a benefit rather than a detriment when it comes to grappling with power in all its forms, by framing those concerns in a fashion that actively engages scholars and readers across political science and beyond.

Our working assumption at Perspectives on Politics is that political theory's pluralism can indeed be a source of strength rather than weakness in fulfilling this aim. The theory articles featured in the journal reflect our understanding of it as the discipline's "public sphere," a view articulated by our predecessor, Jeff Isaac. This means that the political theory appearing in our pages is both problem-driven and focused on matters of broad public concern. This work is integrative, and often freely crosses the increasingly blurry lines between subfields (Isaac 2015). Crucially, it also means that political theory articles in Perspectives, while they display deep scholarship, are shorn of excessively specialized or subfield-specific jargon. They are meant to be read and understood not only by a wide range of political theorists, but also by as many nontheorists, non-political scientists, and members of the broader reading public as possible. Accordingly, theorists who write with the intention of publishing in this journal must self-consciously seek to articulate the wider ramifications of their work, and diligently build bridges to scholars and readers who are unlikely to share either their particular research interest or their preferred approach to it. This is a high bar, but it's worth noting that we apply the same criteria equally to authors from every other subfield as well.

Thus, we see the problem not so much as one of the multiplicity of perspectives within political theory (or any other field), but rather of whether those methodological perspectives are connected to problem-driven research that is expressed in an idiom that transcends subfield insularity and addresses issues of public import. Put differently, our approach to publishing political theory (as with publishing everything else) emphatically continues the mission of the journal, stressing the necessarily perspectival, argumentative, and provisional rather than definitive character of what we publish (Isaac 2015, 279). The goal of the research published here is to illuminate important problems in new ways, not to settle them once and for all (which we regard as an impossible and misbegotten enterprise in any event). With respect to interrogating "the political" from the standpoint of political theory, our philosophical view is close to Nietzsche's, who wrote: “There is only a perspective seeing, only a perspective 'knowing'; and the more affects we allow to speak about one thing, the more eyes, different eyes, we can use to observe one thing, the more complete will our 'concept' of this thing, our 'objectivity', be" (Nietzsche 1989, 119). Given an inevitably agonistic conception of the political and the lack of an Archimedean point for understanding it, our view is that methodological and substantive pluralism of all sorts may be the only way of leading us to a clearer and deeper understanding of politics.

What this editorial philosophy means practically is that Perspectives on Politics does not publish a particular "type" of political theory, but is open to an extremely wide range of approaches and topics, so long as they meet the criteria outlined here. So far, we have published a piece informed by "realism" and non-ideal theory on the relationship between coercive disobedience and justice (Guy Aitchison, "Domination and Disobedience: Protest, Coercion, and the Limits of an Appeal to Justice"); a deliberative democratic critique of the potentially deleterious civic consequences of state "nudging" (Mark Button, "Bounded Rationality without Bounded Democracy: Nudges, Democratic Citizenship, and Pathways for Building Civic Capacity"); and a Frankfurt School critical theory assessment of the Trump presidency (David Lebow, "Trumpism and the Dialectic of Neoliberal Reason"). Future issues will include a democratic theory article that argues that political legitimacy requires balancing the twin goals of democracy and security in the context of large-scale 
migrant influxes (Patti Tamara Lenard and Terry Macdonald, "Democracy versus Security as Standards of Political Legitimacy: The Case of National Policy on Irregular Migrant Arrivals"). We will also feature work in comparative political theory that makes the case for more closely linking that approach to methods used in the subfield of comparative politics-as well as Marxian ideology critique - in order to better understand a wide range of non-Western and Western theoretical traditions that continue to impact global politics (Joshua Simon, "Institutions, Ideologies, and Comparative Political Theory" [doi:10.1017/S1537592719001178]).

\section{The Special Section}

In the current issue, we have four special section articles that exemplify this perspectival approach to political theory. As with those just mentioned, what makes these articles compelling is not the particular theoretical tradition from which they take inspiration, but rather the ways in which they deploy that framework to highlight an important contemporary political problem in a fashion that is simultaneously highly scholarly and broadly accessible to non-specialists.

In our first article, "Reparations for Police Killings," Jennifer Page uses the tools of analytical political philosophy to make a normative case for "reparative justice" in the aftermath of policing killings of "non-liable" African Americans in a society marked by a history of racism. Page argues that monetary and other forms of both material and symbolic redress, such as an official apology, offer a nonadversarial alternative to civil litigation rooted in the concept of "institutional-agent regret," rather than moral responsibility, in the absence of criminality.

In "An Adversarial Ethics for Campaigns and Elections," Samuel Ely Bagg and Isak Tranvik ask what sorts of normative considerations ought to guide candidates running for political office in democracies. Relying on the tradition of "democratic realism," Bagg and Tranvik maintain that existing approaches to campaign ethics inadequately describe political reality and rely on a series of unenforceable norms that have the perverse consequence of driving ethical candidates from the field. Instead, they defend an alternative approach to campaign ethics, one which they believe allows candidates greater flexibility in their appeals to voters, while also adhering to the democratic norms of social and political pluralism.

In our third piece, Ana Tanasoca takes up a different set of concerns about democracy and elections in "Against Bot Democracy: The Dangers of Epistemic Double-Counting." Utilizing a deliberative democratic approach, Tanasoca turns to the question of how we form the individual political judgments that underpin our voting behavior. She argues that the repetition of messages through bots or retweets can lead people to place too much importance on information they have already received, thereby leading to distorted judgments. She concludes by advocating a range of deliberative norms to prevent this from happening, and puts special responsibility on opinion leaders to prevent its occurrence by shielding their audiences from such clone information.

Our final piece for this special section is Mathias Thaler's article, "Peace as a Minor, Grounded Utopia: On Prefigurative and Testimonial Pacifism." Thaler critiques just war theorists in a novel fashion: not by running away from the claim that pacifism is "utopian," but instead by asking how, precisely, we should understand what is meant by utopianism and defending a rearticulated version of that concept. Thaler argues that "grounded utopianism" seeks the emancipatory potential already embedded, if latent, in a status quo characterized by conflict and contestation. As such, he insists, pacifism is rightly understood as rooted in a form of political imagination about a better future that does not turn away from the "real" world, but rather is born of it.

In various ways, all of the political theory articles mentioned here, whether past, current, or forthcoming, speak to the virtues of a deeply pluralistic subfield grappling in various ways with matters of real public concern in engaging and accessible fashion. We are proud to publish them, and look forward to the multiple theoretical perspectives on politics that come over the transom to us in the future.

\section{Our Other Offerings}

The remainder of the issue also offers a rich diversity of articles. "The Paris Agreement on Climate Change-Made in USA?" by Majana Milkoreit discusses how President Obama was able to overcome the dual constraints of significant domestic opposition and national differences on an international climate change accord. She argues that Obama was able to create sufficient international support by proactive engagement with China, and negotiated a treaty without legally binding obligations thus avoiding Congressional ratification. Of course, in retrospect, we can now see how this made it much easier for the Trump administration to walk away from the Paris Agreement.

Pavielle Haines, Tali Mendleberg, and Bennett Butler explore the topic of minority representation in both the rhetorical and policy registers in "I'm Not the President of Black America:' Rhetorical Versus Policy Representation." The article addresses the question of President Barack Obama's rhetorical moderation as our first African-American president. In comparison to other recent presidents, they find that Obama's rhetorical representation of minority populations was indeed relatively weak. However, when they examine the policy sphere, Obama offered much stronger representation on race and poverty. So while Obama's rhetoric may well have been muted, his policy proposals strongly represented the interests of the poor and of minority Americans. 
The field of American politics has seen a revival in the critical study of how interest groups affect politics in our country. In "Interest Groups on the Inside: The Governance of Public Pension Funds," Sarah F. Anzia and Terry M. Moe explore the role played by the bureaucratic boards that govern public pensions. They focus on how the actions of public employees and their unions can have deleterious effects that weaken effective government in ways that paradoxically undermine the position of the very employees whose interests they are supposed to defend.

The final article in this issue is "Who Rules the World? A Portrait of the Global Leadership Class." It presents an overview of the global political elite drawn from the Global Leadership Project, a dataset that has compiled a broad range of biographical data about world leaders. Its authors, John Gerring, Erzen Oncel, Kevin Morrison, and Daniel Pemstein, provide a set of comparisons across regions, regime types, and levels of development, and offer an empirical typology of political leaders. Kevin Morrison, one of the founders of the project, died last year. He was a talented comparativist who had made many contributions to the field, and it is hard to gauge what we have potentially lost by his untimely death. We dedicate this issue to his memory.

The issue closes with a Reflection essay by Douglas Lemke- "State Making Lessons for International Relations Research." In line with our commitment to dialogue between the subfields, Lemke argues that a range of international relations literatures would benefit from greater attention to the comparative politics literature on state-making, in particular its focus on capacity and legitimacy. He argues that such a focus would lead to a plethora of new research topics and lead to important modifications in research design, thereby opening a new agenda in international relations and breathing new life into perpetual topics of interest in the field.

\section{References}

Gunnell, John. 1993. The Descent of Political Theory: The Genealogy of an American Vocation. Chicago: University of Chicago Press. 2015a. "Pluralism and the Fate of Perestroika: A Historical Reflection.” Perspectives on Politics 13(2): 408-15. - 2015b. "A Response to Commentators." Perspectives on Politics 13(2): 429-30.

Isaac, Jeffrey C. 2015. "For a More Public Political Science." Perspectives on Politics 13(2): 269-83.

Nietzsche, Friedrich. 1989. On the Genealogy of Morals and Ecce Homo. Ed. Walter Kaufmann. New York: Vintage Books.

Norton, Anne. 2015. "Perestroika and the Struggle for Politics." Perspectives on Politics 13(2): 425-26. 


\section{Statement of Mission and Procedures}

Perspectives on Politics seeks to provide a space for broad and synthetic discussion within the political science profession and between the profession and the broader scholarly and reading publics. Such discussion necessarily draws on and contributes to the scholarship published in the more specialized journals that dominate our discipline. At the same time, Perspectives seeks to promote a complementary form of broad public discussion and synergistic understanding within the profession that isessential toadvancing scholarship and promoting academic community.

Perspectives seeks to nurture a political science public sphere, publicizing important scholarly topics, ideas, and innovations, linking scholarly authors and readers, and promoting broad reflexive discussion among political scientists about the work that we do and why this work matters.

Perspectives publishes work in a number of formats that mirror the ways that political scientists actually write:

Research articles: As a top-tier journal of political science, Perspectives accepts scholarly research article submissions and publishes the very best submissions that make it through our double-blind system of peer review and revision. The only thing that differentiates Perspectives research articles from other peer-reviewed articles at top journals is that we focus our attention only on work that in some way bridges subfield and methodological divides, and tries to address a broad readership of political scientists about matters of consequence. This typically means that the excellent articles we publish have been extensively revised in sustained dialogue with the editors to address not simply questions of scholarship but questions of intellectual breadth and readability.

"Reflections" are more reflexive, provocative, or programmatic essays that address important political science questions in interesting ways but are not necessarily as systematic and focused as research articles. These essays often originate as research article submissions, though sometimes they derive from proposals developed in consultation with the editor in chief. Unlike research articles, these essays are not evaluated according to a strict, doubleblind peer review process. But they are typically vetted informally with editorial board members or other colleagues, and they are always subjected to critical assessment and careful line-editing by the editor and editorial staff.

Scholarly symposia, critical book dialogues, book review essays, and conventional book reviews are developed and commissioned by the Associate and Book Review Editor, based on authorial queries and ideas, editorial board suggestions, and staff conversations.

Everything published in Perspectives is carefully vetted and edited. Given our distinctive mission, we work hard to use our range of formats to organize interesting conversations about important issues and events, and to call attention to certain broad themes beyond our profession's normal subfield categories.

For further details on writing formats and submission guidelines, see our website at http://www.apsanet.org/ perspectives/ 